Article

\title{
Exploring the Relationship between Environmental and Economic Payback Times, and Heritage Values in an Energy Renovation of a Multi-Residential Pre-War Building
}

\author{
Adeline Jerome *, Paula Femenías (D), Liane Thuvander (), Paula Wahlgren (1) and Pär Johansson (i) \\ Department of Architecture and Civil Engineering, Chalmers University of Technology, \\ SE-412 96 Gothenburg, Sweden; paula.femenias@chalmers.se (P.F.); liane.thuvander@chalmers.se (L.T.); \\ paula.wahlgren@chalmers.se (P.W.); par.johansson@chalmers.se (P.J.) \\ * Correspondence: adeline.jerome@chalmers.se; Tel.: +46-31-772-1824
}

Citation: Jerome, A.; Femenías, P.; Thuvander, L.; Wahlgren, P.; Johansson, P. Exploring the Relationship between Environmental and Economic Payback Times, and Heritage Values in an Energy Renovation of a Multi-Residential Pre-War Building. Heritage 2021, 4 , 3652-3675. https://doi.org/10.3390/ heritage 4040201

Academic Editors: Tor Broström and Nicola Masini

Received: 30 August 2021

Accepted: 15 October 2021

Published: 19 October 2021

Publisher's Note: MDPI stays neutral with regard to jurisdictional claims in published maps and institutional affiliations.

Copyright: (c) 2021 by the authors. Licensee MDPI, Basel, Switzerland. This article is an open access article distributed under the terms and conditions of the Creative Commons Attribution (CC BY) license (https:// creativecommons.org/licenses/by/ $4.0 /)$.

\begin{abstract}
Cultural value and heritage have been identified as necessary for a sustainable living environment, alongside environmental concern and energy efficiency. In this study, multiple methods, i.e., life cycle assessment, payback, and questionnaires and interviews with tenants, and empirical data from a recent energy renovation of a multi-residential pre-war building with wooden construction were used to analyse the impact of the renovation on cultural and aesthetic values, environmental impact, financial payback time, and user satisfaction. In the energy renovation, the façade, which had been disfigured in an earlier renovation, was recreated to resemble the original architecture. The main questions are: What impact has the recreation of the façade on the environmental payback time in comparison to a more conventional renovation? What are the consequences for the user satisfaction and financial return on investment? The results show that the recreated façade has improved the building's aesthetics without compromising the environmental benefits. It also resulted in better thermal comfort, which is highly valued by the tenants. The improved aesthetics are also appreciated by the tenants, but to a lesser extent. Financially, the renovation is estimated to be not viable. Results of this study can be applied in the decision-making of similar renovation projects.
\end{abstract}

Keywords: historic buildings; Life Cycle Assessment (LCA); energy retrofit; payback time; heritage value; recreating architectural value

\section{Introduction}

The building and construction sector is responsible for $40 \%$ of the energy consumption and $36 \%$ of the greenhouse gas (GHG) emissions of the European Union [1]. The heating and cooling of residential buildings represent 11\% of the GHG emissions in Europe [2]. With the ambition of reducing Sweden's environmental footprint, the Swedish government set the objective of a 50\% energy consumption reduction for its building stock by 2050 compared to 1995 [3]. This energy efficiency goal is combined with the overall aim to reach zero net GHG emissions by 2045. Therefore, the national recommendation and regulations are strengthened to ensure a high energy efficiency of new buildings. As the replacement rate of the existing stock is slow, emphasis has been placed on developing and applying efficient strategies for energy renovation [4].

Current building regulations limit the maximum energy use of a building during its operational phase. As considerable improvements have been reached in terms of thermal efficiency of contemporary buildings, the impact of the material production and construction phase becomes more significant in the cumulative environmental impact over the life span of a building [5,6]. Moreover, raising concerns for the environmental and carbon impact of human activities have led European governments to push for the inclusion of carbon impact analysis in the planning of new constructions [7]. In Sweden, a new Climate Act came into force in 2018. Swedish law requires climate declarations for new 
constructions starting from 1 January 2021 [8]. Regulations for renovation works are also anticipated; hence, there is a need to develop methods and tools to support environmental declarations for renovations. In parallel with governmental climate initiatives, the Swedish construction sector has signed an action plan towards a fossil free future in which the sector requests strong governmental leadership and encourages clients, consultants, and builders to develop knowledge in the field [9].

This paper takes the perspective of historic residential buildings in Sweden and discusses aesthetic and cultural value and environmental impact of the building process in decisions for renovation. In Sweden, $20 \%$ of all dwellings are found in buildings constructed before 1945 and $28 \%$ in buildings constructed before 1950 [10]. Very few of these historic buildings are formally protected and classified as monuments. According to the Swedish Planning and Building Act (PBL, Plan- och bygglagen) [11], any alteration to a building, new or old, protected or not, should be made with respect to its original character and architecture. For buildings with a high cultural and historic value, often designated in local historic environment programmes, PBL advocates a prohibition against disfigurement. It is up to the building owner and to the local authorities that survey planning and building permits to ensure that the requirements from PBL are followed [12].

The process of finding a suitable renovation strategy is a decision-process for housing owners framed by multiple influencing factors. In order to find sustainable renovation solutions for existing housing, political ambitions for energy savings and climate protection must be balanced with technical needs, social concerns for residents, and the specific economic conditions for each location, owner and building [13]. Multiple factors influence housing renovation with the result that few renovations are actually carried out with the energy efficiency investments that are needed to reach political energy objectives [14]. Furthermore, ambitions for energy savings intersects with objectives for cultural and heritage values of the built environment. The United Nations Sustainable Development Goals (SDGs) and the Agenda 2030 identify culture as an important driver for sustainable development [15]. In Sweden, on the national level, a new architectural policy specifies that the cultural, historical and architectural value of buildings should be preserved and developed to benefit sustainable transitions [16]. In addition, the Swedish National Board of Housing, Building and Planning has emphasised the importance of respecting heritage value and the scarcity of pre-war housing when developing plans for energy renovation of buildings [17].

While the relationship between energy efficiency and the preservation of historic buildings has been well researched [18], life cycle approaches and the use of Life Cycle Assessment (LCA) as a guidance for environmental and sustainable solutions of historic buildings is still rather unexplored [19]. The importance of including a life-cycle perspective in decision-making is stressed by the European Committee for Standardization (CEN), in the European standard for energy efficiency in historic buildings "Guidelines for Improving the Energy Performance of Historic Buildings" [20]. Furthermore, existing buildings represent an embodied environmental impact [21,22]. Consequently, besides the large societal and cultural value of historic buildings, their preservation also has benefits with respect to environmental impact compared to new constructions [23]. In this respect, existing buildings hold a key role in the current transition towards resource-efficiency and the circular economy [24].

A review of studies exploring LCA as a decision-making tool for renovations concludes that energy renovation measures are beneficial from both energetic and environmental perspectives [22]. This review stresses that results from study to study are hardly comparable due to a great variability in the scope and methodological choices. A review with a specific focus on cultural heritage buildings and environmental impact confirms the great variety of assessment methods, including LCA, as well as the variation of chosen environmental indicators [23]. Earlier studies are mainly based on theoretical renovation scenarios, and only a few consider empirical studies with real data and monitored impact of energy retrofit measures, such as the one from Ardente et al. [25] 
Previous LCA studies on renovations also often focus on post-war housing [22], and only a handful on pre-war housing. Ardente et al. [25] studied the renovation of six old public buildings, some of them from the 19th century, and concluded with energy and carbon payback times lower than three years. When studying the thermal improvements of a Victorian terraced house from the 19th century, Mohammadpourkarbasi and Sharples [26] found that the payback in terms of $\mathrm{CO}_{2}$ emissions is lower than seven years. Other LCA studies of building renovation compare the refurbishment of historic buildings with new energy-efficient ones as a means to cast light on the benefit of reuse of buildings [27,28]. A study published by the American National Trust for the Historic Preservation concludes that building reuse typically offers greater environmental savings than demolition and new construction [28]. Berg and Fuglseth [27] compared the careful renovation of a historic Norwegian villa, with respect to preserving its original characteristics, with a scenario of replacing the old villa with a new one. The study shows that replacing with a new construction would take more than 50 years to pay back in term of greenhouse gas emissions, but also underlines the critical influence of user behaviour estimation on energy performance modelling. The authors argue for a modified user energy consumption profile, with a lower energy use, that reflects the actual behaviour of residents in historic buildings. From the perspective of sustainability, these previous LCA studies have been limited to environmental aspects without considering the perspective from residents, the financial side of the renovation, or the potential impact on the buildings' cultural and aesthetic values.

This paper aims at contributing to the field of sustainable renovation of historic buildings by calculating the payback time for primary energy and carbon emissions of a renovation in relation to the financial investment payback and to discuss the influence of renovations on the building's cultural and aesthetic value, and user satisfaction. A recent energy retrofit of a pre-war multi-residential building in Sweden was selected as a case, with good data availability and which is representative of a local pre-war building typology. In the case building, a wooden façade, which had been replaced by asbestos boards in an earlier renovation, was recreated to reinstall the building's architectural and cultural value. The case is interesting as the energy renovation becomes a means for improving the cultural value of a historic building. The questions of our study are: How long is the payback time of the chosen renovation solution in terms of energy, carbon emissions, and financial investments? How different are the environmental payback times compared to a conventional renovation without the ambitions to recreate cultural values? What is the impact of the renovation on the building's physical appearance and the user satisfaction? The study has no intention of advancing LCA methodology, but instead uses easily accessible tools and methods on a case, providing empirical data from a recent energy retrofit.

\section{Materials and Methods}

Energy renovation has been studied from three different perspectives: (1) the environmental impact, estimated with an LCA, (2) the economic aspect, based on an estimation of the economic payback time of the renovation, and (3) the tenants' perspective of the results and the cultural value of the renovation, based on a questionnaire study followed up with complementary in-depth interviews with six tenants. Together with a description of the motivation and the decision behind the energy retrofit, these perspectives provide material to discuss the benefit of the renovation from an environmental, financial, as well as a social and cultural perspective.

General information on the case study is retrieved from several data sources: the building permit archive (for drawings and related documents), the local Historic Environment programme [29] for descriptions of the local history and the cultural historical value of the studied building, documents provided by the property owner and the building contractor with energy and material use data, a questionnaire and in-depth interviews with tenants in the area. In order to understand the motivation and the decisions taken in the energy renovation, semi-structured interviews were made with: a representative (project leader) 
from the property owner, the architect for the energy retrofit, the CEO of the contractor that carried out the renovation, and the municipal servant responsible for the building permit for the energy retrofit. Some additional information has been retrieved in follow-up correspondence with these actors. All interviews were recorded and transcribed.

\subsection{Case Study Selection}

The selected case represents a contemporary energy renovation of a historic residential building that was already renovated, which is the case with older residential buildings. An earlier study estimates that $71 \%$ of the Swedish housing stock built between 1931 and 1945 has already been renovated one or several times [30]. The case also represents a renovation where a façade, which was disfigured and covered with fibre cement boards in an earlier renovation, has been recreated in order to reinstall the building's original architectural value. Consequently, the case provides a base for discussing the cultural value in energy renovation in comparison with a conventional renovation where the heritage value is not considered.

The case building is a "Landshövdingehus", a typical local working-class housing typology in Gothenburg commonly built between the 1860s and the 1940s. The building typology is found in only a few other cities in Sweden. "Landshövdingehus" are characterised by a first level built with bricks and two levels with a timber construction, a measure to circumvent the fire regulations, which prohibited timber constructions with more than two levels at that time. In Gothenburg, $60 \%$ of all the remaining pre-war multi-residential buildings belong to this typology.

There is no general protection of this typology, and no more than a handful are classified as monuments. A majority of the remaining "Landshövdingehus" are described in the local Historic Environment programmes [24], more often as part of a valuable neighbourhood rather than as individual buildings. Generally, the Historic Environment programmes are a source of knowledge about the history and heritage value of the local built environment. Even if the programmes do not provide any formal protection, these are consulted when a building permit is handled.

Swedish energy saving programmes (1974-1983), launched in the wake of the first oil crises, resulted in a first wave of energy renovations of housing [31]. Advantageous loans were offered to housing owners who implemented measures to upgrade the heating systems, replace oil heating, and reduce the operational energy demand through additional exterior insulation and more energy efficient windows. The loans mainly targeted building housing from the pre-war and war periods, as those buildings had the highest energy use. The energy loans were introduced without the consideration of potential negative visual impacts and influences on aesthetics and heritage values [32]. The applied exterior energy measures, such as additional insulation, new façade materials, and the replacement of windows, have been criticized for their lack of consistency with the buildings' original architecture that resulted in a disfigurement of older housing stocks [33]. Wooden façades of the "Landshövdingehus" were often replaced by what the property owners expected to be low maintenance steel panels or composite boards [34].

Now, 40 to 50 years after the first energy renovations, these buildings are again in need of renovation and modernisation. Consequently, energy improvements are carried out among these previously renovated and often disfigured "Landshövdingehus". The new renovations offer the possibility to recreate architectural and cultural values that have been lost in earlier renovations, an opportunity to improve the aesthetics. An increasing number of such recreations have been observed, and this gives the indication that recreation of lost architecture is attractive for some property owners [35].

The selected case is representative in the sense that other types of timber constructions, including detached and semi-detached villas, as well as smaller multi-residential buildings all over Sweden, have been renovated in similar ways during the energy saving programmes in the 1970s and 80s [36]. Similar situations are also found in other locations, 
for example in Estonia where older wooden multi-residential buildings were clad with chip boards and plaster during the second half of the 20th century [37].

\subsection{Description of the Case Building and the Energy Retrofit}

The case building (Figure 1) is located in the Eastern part of Gothenburg. It was built in 1937 as a "barnrikehus", which was a type of social housing targeted for families with many children. The area provided, for the time being, modern facilities, such as central heating and a bathroom. The building is currently owned and managed by a municipally owned housing company that owns and manages more than 26,000 rental apartments in the city. The building has 36 rental apartments with a heated floor area of $2674 \mathrm{~m}^{2}$ according to its energy performance certificate (EPC) realised in 2016. In 1979, the original wooden cladding on the upper two levels was covered by cement fibreboards reinforced with asbestos, probably in a bid to protect against rain and to lower the maintenance costs due to a recurrent need to re-paint the wooden façade. For unknown reasons, no insulation was added to the façade at that time. The fibre-cement boards had a negative impact on the visual experience and historic value of the building, and the energy efficiency remained poor. The building is mentioned in the local Historic Environment programme, which suggests that the recreation of the wooden façade is possible [29].

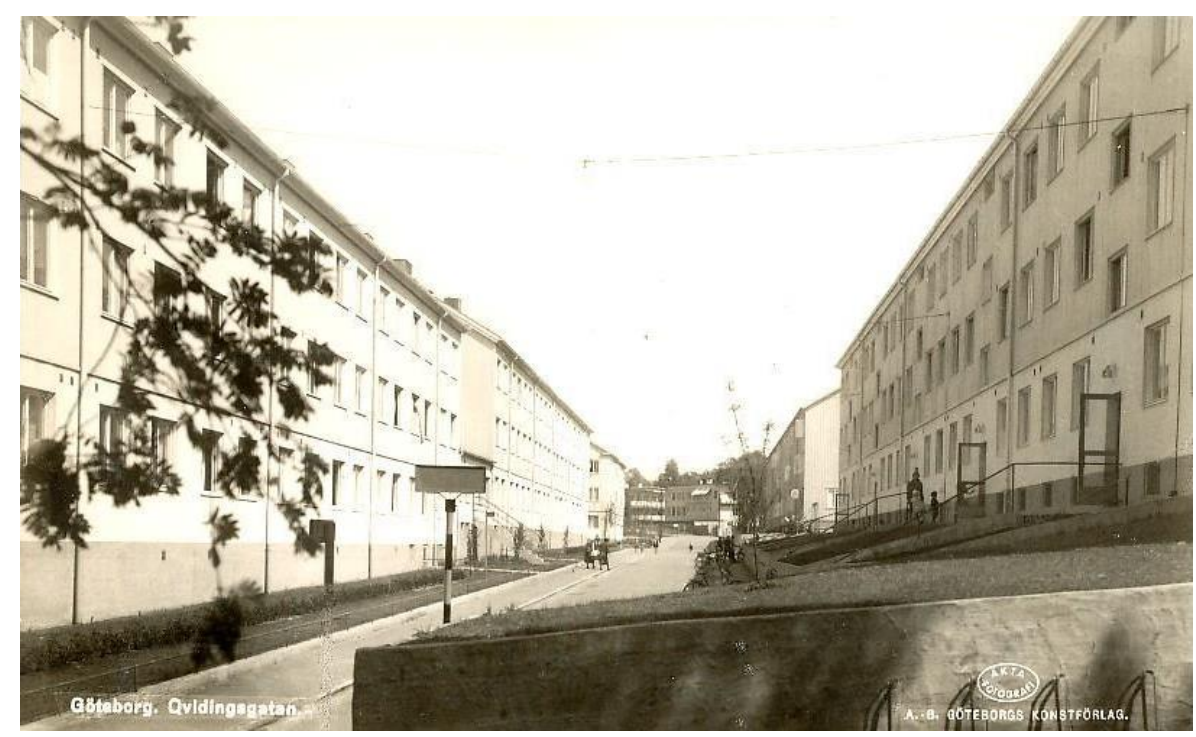

Figure 1. Case building, to the right, in the 1940s. Photo courtesy of Gothenburg City Museum.

In 2016, a new renovation was initiated by the housing company with the aim to improve the building's energy efficiency and thermal comfort. The energy renovation was a pilot project to test a technical solution to be implemented in other buildings in the area, as well as in the rest of the pre-war housing stock of the housing company. An external consultant estimated potential energy savings for both individual energy saving measures and a package of measures in order to support the decision for renovation. The embodied environmental impact of the renovation work and the production of materials were not evaluated at that time, as this is usually only done when specifically required; for example, when aiming for certain eco-labels. Several energy retrofit measures were selected to improve the building envelope:

- addition of thermal insulation on the roof with $100 \mathrm{~mm}$ of phenolic foam, with new roof framing elements and the replacement of all roof tiles, including security equipment (snow fences and walkways);

- addition of exterior thermal insulation on the façade and the replacement of cladding materials: $70 \mathrm{~mm}$ of mineral wool and wooden panels to replace asbestos board on the upper part of the façade, and expanded polystyrene covered by plaster on the lower part; 
- replacement of the original 2-pane windows with 3-pane windows with better thermal properties;

- replacement of the external doors.

The heating and ventilation system was not changed, leaving the building with a natural ventilation system and a connection to the district heating system in Gothenburg for heating and hot water.

The original idea from the owner was to replace the old asbestos fibre-cement boards on the façade with new fibre-cement boards. This is currently a popular façade material in Sweden, both in new construction and renovation due to its low maintenance. In the process of obtaining the building permit for the renovation, the City Planning office planted the idea of a re-creation of the wooden façade, with a reference to the local Historic Environment programme. The City planning office, however, has no legal rights to request the recreation of a previously lost appearance. In line with PBL, the present physical appearance of the building should be respected and not disfigured, which would then be the 1970 s board façade.

The idea of recreating the wooden façade was considered by the property owner who decided to choose that option. An architect was consulted to plan for the recreation. It is not a restoration, as the recreated façade differs from the original. The original façade was plain, without any cover lists and a light chrome oxide green. The characteristics of the original façade were not known during the design and planning of the renovation and were only revealed once the fibre-cement boards were removed. The architect took inspiration from buildings in the surroundings and decided for a light-yellow wooden façade with cover lists (a solution which was easier to build and thus preferred according to the constructor) and a grey plaster on the ground level.

When adding the insulation and the new façade, the new windows were moved outwards, onto the level of the insulation, to be aligned with the new outer façade. The outer alignment of windows in the façade is typical of older timber constructions in Sweden, and the measure was made to create a more authentic look of the old façade. Moving the windows involved challenges with cold bridges and the façade had to be remediated by the contractor [34]. At the ground level, the exterior walls were insulated on the outside, and a new plaster façade was added, without moving the windows.

The architect had prescribed similar side-hinged wooden windows to the original, which opens outwards. The building company, on a design and build (turnkey) contract, chose instead to use pivot-hinged windows with a false centric mullion, which severely compromised the aesthetical appearance and authentic historic reference of the building (Figure 2). 


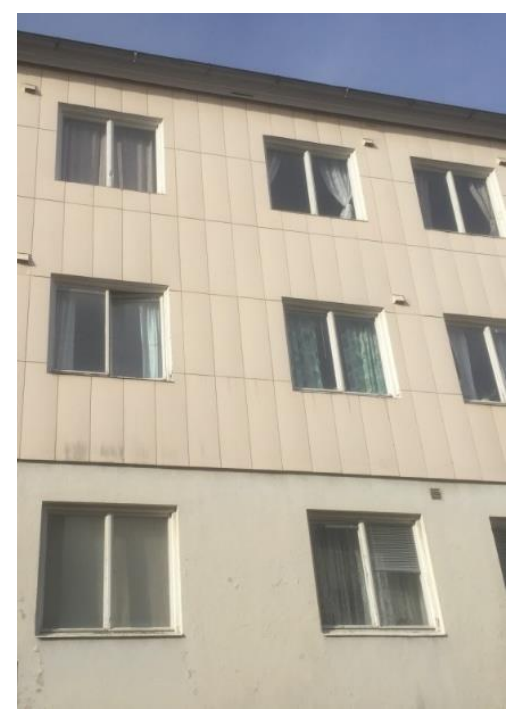

(a)

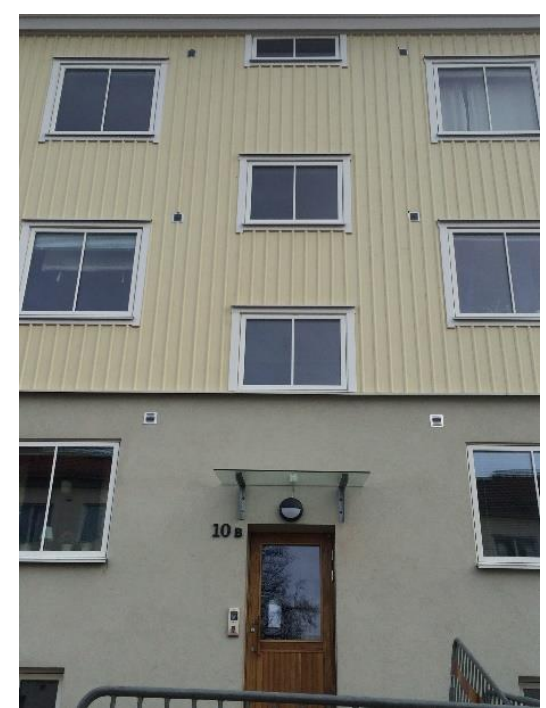

(b)

Figure 2. (a) The fibre-cement board façade with the original side-hinged windows on an adjacentand still not renovated-building block in the same street. Photon K. Mörk, 2017. (b) The recreated wooden façade with the pivot hinged windows and false centric mullions. Photo L. Thuvander, 2017.

\subsection{Goal and Scope of the LCA}

LCA for buildings was developed to analyse the environmental impact of a building from its construction to its end-of-life. The European standard EN15978 details its procedure, which is divided into four main steps: the goal and scope definition, the life cycle inventory, the assessment of the selected environmental indicators and the interpretation of the results. To calculate the environmental impact of building renovations, the standardised methodology, tailored for new constructions, must be adjusted. Renovation moves from being only a life cycle stage of the building to the central element of the study.

Various tools are developed to support the use of LCA as a decision tool for renovations. In the literature, LCA is integrated in some decision support tools for renovations [38], but the exact methodology and processes accounted for in the assessment are often not easily accessible, such as the one developed by Mjörnell et al. [39]. Another tool, developed by the Swedish environmental institute [40], only aims to estimate the embodied impact of new construction materials for the renovation, which makes the comparison of different renovation scenarios, leading to different energy performances over the lifetime of the building difficult. For this study, it was then decided to use an Excel tool developed to perform the calculations detailed in Section 2.4.

In this study, the environmental LCA aims to assess the net energy and carbon savings generated by the second renovation of the building presented above over a service life of 50 years, and to compare the impact of choosing a wooden façade, for cultural value recreation, instead of fibre-cement boards. Two attributional LCAs are conducted. One focuses on the real renovation, with a wooden façade, implemented on the building, hereafter referred to as 'real renovation'. The second one is used to assess an alternative scenario with $10 \mathrm{~mm}$ fibre-cement boards as a façade cladding material, instead of wooden panels, indicated as the 'alternative renovation'. The other elements in the renovation (i.e., the addition of exterior insulation, the replacement of windows and doors, and the renovation of the roof) are assumed to be kept in the 'alternative renovation' scenario, with the same material quantities as for the real renovation. It is assumed that the building would have the same thermal performances in the two cases. The functional unit in the two studies is to provide a multi-family housing with a heated floor area of $2674 \mathrm{~m}^{2}$ for 50 years. A service life period to last as long as possible is anticipated. However, the building is expected to face its next major renovation after 50 years of use; therefore, we have set the service life to be 50 years. Two impact categories are considered in the 
assessment: the cumulated primary energy consumption, including renewable and nonrenewable sources of energy, expressed in $\mathrm{MWh}$, and global warming potential over a 100-year time-horizon (GWP), expressed relative to $\mathrm{CO}_{2}$. The following life-cycle stages were taken into account, based on the recommendations from Vilches et al. [22]:

- the production of the new components for the refurbishment, including the extraction of raw materials, their transportation and manufacturing;

- the transport of the new components to the construction site and their installation (renovation work);

- the end-of-life of the wastes generated by the renovation;

- the energy use of the whole building after the renovation, with the assumption that the yearly energy use is constant during the 50 years of building use;

- possible further replacements (end-of-life treatment and production of materials for the replacement) of the new materials added during the renovation work if their intended lifespan is shorter than 50 years. However, the maintenance of new materials, such as the re-painting of the façade for example, is not included in this study.

A simplified flowchart of the processes included in the assessment is presented in Figure 3.

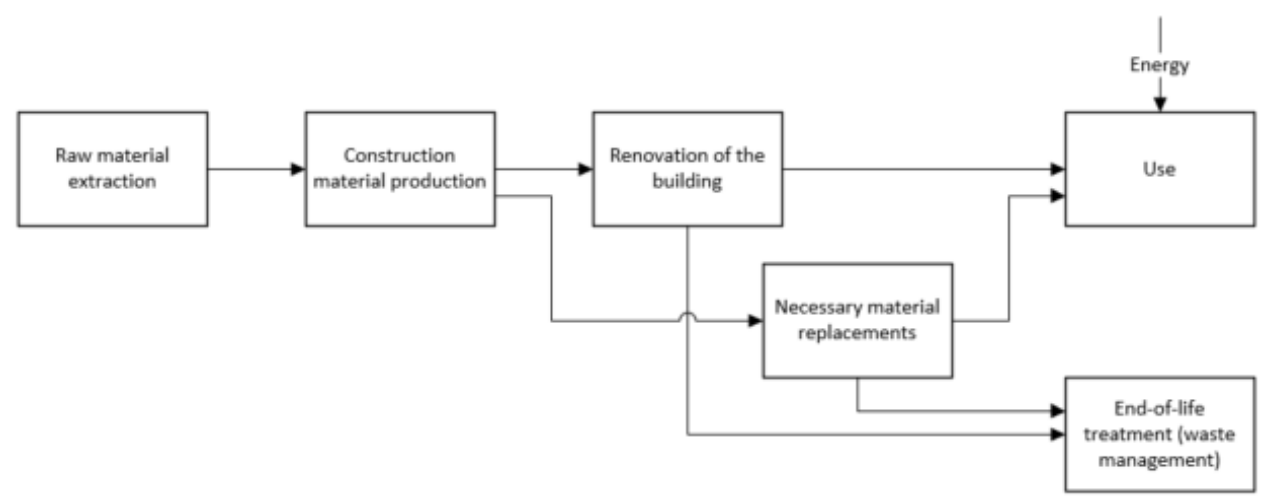

Figure 3. Simplified flowchart of the processes included in the life cycle assessment.

\subsection{Data Inventory and Calculations for the LCA}

The raw material extraction, production, installation, and end-of-life of construction materials were modelled based on manufacturer's product data and from environmental product declarations (EPD). When no EPD was available, the inventory was completed by generic data from license-free European environmental databases for construction materials Ökobaudat [41] and Ökobilanzdaten [42]. For more information on the selected datasets, see the Supplementary material, Section S.1.1.

To model the renovation of the building, the quantity and relevant characteristics of added and removed construction materials were collected from bills provided by the contractor. The weight and composition of waste removed during the renovation was retrieved from information sent to the contractor by the waste treatment plants. The quantities and the product names of the new construction materials and components were gathered from purchase order forms and technical documents. An estimation of their transportation from the production place to the renovation site was made based on the information of the location of the production sites. More information of the modelling of transport is available in the Supplementary material, Section S.1.2.

The energy use of the building during its use after the renovation was estimated with two methods for each case: (1) a thermal simulation of the building prior to the renovation work, and (2) a projection of the energy use based on real consumption data after the renovation. For both methods, a yearly consumption was estimated and assumed to be constant over the lifespan of the building after renovation. The modelling of an energy consumption evolving with time would have given a more accurate estimation of the future impacts of the building, but, as the main aim of the study is the comparison of two 
choices for the renovation, this type of modelling was deemed to be out of the scope of this study. The thermal simulation of the building was performed by a consultancy company during the preparation of the renovation to support the property owner in the decision process. An estimation of energy savings generated by each energy saving measure and by the renovation as a whole was retrieved. For the projection based on real data, the housing owner provided detailed energy use information, with the amount of energy for heating and electricity on its bills for the years 2017 and 2018. The provided values are normalised values according to a 'normal year' (without extreme climatic situations). The average energy use over the years 2017 and 2018 was used in the calculation. The building energy use after the renovation from the two methods are compared to the average energy use between 2005 and 2015 and were reported on the housing owner's bills to estimate the energy savings achieved with the renovation.

Data for the efficiency of the energy production and the GWP for the production of district heating and electricity were retrieved from the report from Liljenström et al. [5] (see Supplementary material, Section S.1.3).

To estimate the impact of the construction material over the use phase of the building, their replacement rate was taken into account. It was assumed that their maintenance, such as repainting or cleaning, would represent a negligible environmental impact over their life cycle, and that a need for repair would lead to the replacement of the material. To model the replacement of materials, it was assumed that they would be fully replaced at the end of their lifespan. Specific instructions for Swedish owners about maintenance were used to estimate the lifespan of the different materials [43,44] (Table 1).

Table 1. Estimation of the lifespan of products used for the Life Cycle study $[43,44]$.

\begin{tabular}{cc}
\hline Element & Lifespan (Years) \\
\hline Roof tiles, roofing felt and roof security equipment & 30 \\
Roof insulation and new roof framing elements & 50 \\
Façade insulation & 50 \\
Wooden panels & 40 \\
Plaster & 30 \\
Windows & 40 \\
Doors & 35 \\
\hline
\end{tabular}

Calculations were performed in Excel. The global impact of the renovation was estimated based on the following formula:

$$
\text { Global impact }=L S \cdot\left(\left(H_{e}+W_{e}\right) \cdot f_{\text {heat }}+\text { Elec } \cdot f_{e l}\right)+E I+I_{\text {materials, }, \text { se }}+I_{\text {materials }, \text { EoL }}
$$

with LS the lifespan of the renovation, estimated to 50 years, $H_{e}$ the space heating energy after the renovation $\left(\mathrm{kWh} /\right.$ year), $W_{e}$ the hot tap water energy after the renovation (kWh/year), Elec the electricity consumption after the renovation ( $\mathrm{kWh} /$ year), $f_{\text {heat }}$ and $f_{e l}$ the corresponding conversion factor between delivered energy and the indicator (unit of the indicator $/ \mathrm{kWh}$ ), EI the embodied impact of the renovation, and $I_{\text {materials, use, }} I_{\text {materials, EoL }}$ the impact due to the use and end-of-life treatment respectively of substituted and new materials (unit of the indicator):

$$
\begin{gathered}
E I=\left(\sum_{j} Q_{j} \cdot\left(I_{j, \text { prod }}+I_{j, \text { cons }}\right)\right)+I_{\text {wastes }, \text { EoL }} \\
I_{\text {materials }, \text { use }}=\sum_{j} Q_{j} \cdot\left(I_{j, \text { prod }}+I_{j, \text { cons }}+I_{j, \text { EoL }}\right) \\
\cdot \text { floor }\left(L S_{j} / L S\right) \\
I_{\text {materials }, \text { EoL }}=\sum_{j} Q_{j} \cdot I_{j, \text { EoL }}
\end{gathered}
$$


with $Q_{j}$ the quantity of material $j(\mathrm{~kg}), I_{j, p r o d}, I_{j, \text { cons }}$ and $I_{j, E o L}$ the energy impact of the material $j$ generated during its production, construction and end-of-life phase respectively (unit of the impact $/ \mathrm{kg}$ ), $L S_{j}$ the lifespan of material $j$ (years), and $I_{\text {wastes, EoL }}$ the impact due to the end-of-life treatment of construction wastes during the renovation work.

The payback time $(P B T)$ was calculated as follows:

$$
P B T=E I / \text { Impact }_{\text {saved } / \text { year }}
$$

with Impact saved/year being the estimated yearly savings thanks to the retrofit (unit of the indicator/year).

\subsection{Economic Payback Time}

The owner provided the investment cost for the renovation work and the revenue in the form of a rent increase. As those data were available only for the real renovation, no estimation for the economic payback time has been made for the alternative renovation scenario in this study. No range of rents has been used in the calculation, as this was not considered justified or probable. In Sweden, rent increase for rental housing is the result of a negotiation between the Swedish Housing Association and the property owner and is based on what is called "utilisation value" [45]. Costs for "normal maintenance" (for example external renovation) and energy efficiency cannot be transferred to the tenants (except partly for example for new windows, which is considered a standard improvement as this will lead to better indoor climate for the tenants), only costs for standard improvements (e.g., new improved kitchen, wooden flooring, improved security through new doors and security systems). In the specific case of renovation, which is discussed in the paper, the tenants opposed to a more comprehensive renovation that was initially planned and that included internal renovation and consequently standard improvements-this delayed the whole renovation process for almost two years.

Information to estimate the annual main expense for the owner with respect to the building energy use, electricity and district heating prices and their expected increase rate for the next 50 years was retrieved from Brown et al. [46] (Table 2) A simple evaluation of the economic payback time (PBT) of the renovation was then estimated as the results of the following equation:

$$
\begin{aligned}
R C= & P B T \times B_{\text {rent }}-\frac{1-\left(1+r_{e l}\right)^{P B T+1}}{r_{e l}} P_{e l}\left(C_{\text {el, before }}-C_{\text {el, after }}\right) \\
& -\frac{1-\left(1+r_{\text {heat }}\right)^{P B T+1}}{r_{\text {heat }}} P_{\text {heat }}\left(C_{\text {heat }, \text { before }}-C_{\text {heat }, \text { after }}\right)
\end{aligned}
$$

with $R C$ the renovation cost, $B_{r e n t}$ the economic benefit generated yearly by the increase of the rent, $r_{e l}$ and $r_{\text {heat }}$ the rate of yearly price increase for electricity and heat, $P_{e l}$ and $P_{\text {heat }}$ the current price for electricity and heat, $C_{\text {el, before/after }}$ and $C_{\text {heat }}$,before/after the electricity and heat consumption before/after the renovation.

Table 2. Parameters for the economic assessment.

\begin{tabular}{cc}
\hline Parameter & Value \\
\hline Renovation cost $R C$ & $10.5 \mathrm{M} \mathrm{SEK}$ \\
Yearly benefit from rent increase $B_{\text {rent }}$ & $108 \mathrm{kSEK}$ \\
Yearly price increase for electricity $r_{e l}[46]$ & $2.5 \%$ \\
Yearly price increase for heat $r_{\text {heat }}[46]$ & $1.4 \%$ \\
Current price for electricity $P_{e l}[46]$ & $0.96 \mathrm{SEK} / \mathrm{kWh}$ \\
Current price for heat $P_{\text {heat }}[46]$ & $0.64 \mathrm{SEK} / \mathrm{kWh}$ \\
\hline
\end{tabular}

This estimation does not account for the predicted maintenance costs and is therefore a first approximation of the minimum economic payback time of the renovation for the owner of the building. 


\subsection{The Tenants' Perspective}

A questionnaire was sent out to the tenants in the case building as well as to a few adjacent building blocks in the same area. The questionnaire survey was conducted in 2017 , after the renovation of the case building but prior to the renovation of other building blocks in the same area. That means that the questionnaire captured the tenants' experience of the renovation process and its result in the case building, and the tenants' expectations on the renovation in the adjacent buildings. A printed version of the questionnaire was placed in the tenants' letter box together with a prepaid franked return envelope. In total, 156 tenants in the area received the questionnaire of which 73 responded (response rate $47 \%$ ). Of the 36 apartments in the case building, respondents from 17 household filled in the questionnaire.

The questionnaire had three parts (A-C); part A with questions about the household and its demographics; part $\mathrm{B}$ with general questions of the appreciation of the housing area and of the tenant's own dwelling, why the tenant decided to move to the area, and their appreciation of the building's history and its cultural value; and part $C$ with questions about the renovation process and its results, if they appreciated the recreated façade and if they experienced a better indoor comfort. In part C, a question was posed on the tenants' willingness to pay for heritage values in comparison to their willingness to pay for other values that could be attributed the renovation: the improved environmental profile of their home, the improved indoor comfort and improved sound insulation as a result of the new windows.

The average age of the respondents of the questionnaire is high and few have children under 18 living at home. Most of the respondents are female. The demographics of the respondents are typical for the area, with older housing and rather small apartments of mainly 2 rooms, a kitchen and a small bathroom. Characteristic for the respondents is that they have lived in the area for a longer time, in average 15 years. Nine of the tenants have lived in the area more than 40 years, which is far beyond the national average, which is living seven years at one location [47]. However, 31 of the total 73 respondents have lived less than eight years in their apartment.

In the questionnaire, all respondents were asked about their willingness to participate in a follow-up face-to-face interview. The aim of the interviews was to get qualitative and explanatory insights that complemented the quantitative data from the questionnaire and the questions posed during the interviews resembled those posed in the questionnaire. The purpose was to deepen the understanding of how the tenants in this case area value heritage values of the building they live in and their apartment, how they perceive the value of the recreated wooden façade, as well as their general experiences of the renovation process and its result.

Of the 73 tenants that sent in a filled in questionnaire, eleven indicated that they were available for a follow-up interview. The research group then made a selection of tenants that represented different household categories (singles, couples and families with children), genders and age groups. Eventually, six of these tenants were available for an interview, which were all conducted during a few days in the early 2018 in the tenants' home. One of these six lived in the renovated case building and the other five in the surrounding blocks, which at the time were not yet renovated. Unfortunately, no couples or families were available during the days the interviews were carried out. The tenant living in the case building was between 80-90 years and had lived in the area since the construction in 1937. Four of the other interviewees were between 60 and 80 years and had lived in the area between 20 and 50 years. Only one interviewee was between 20 and 30 and had lived in the area for six years at the time for the interview. Two of the interviewees were male and four were female. The questionnaire and the interviews were part of a larger study including also other pre-war housing areas which have recently undergone renovation. An interim report from the study has been published in Swedish [48] and an international publication which will present statistical analysis of this larger material and is planned for later publication. 


\section{Results}

\subsection{Results from the Environmental and the Financial Assessment}

The results from the environmental and financial assessment are structured in five sub-sections. They present the results of the inventory for the LCA, the LCA results related to construction materials for the implemented renovation, a comparison of environmental and economic payback times estimated with different energy consumption data, the comparison of the two cases of renovation, and, finally, an uncertainty analysis with respect to environmental data of the energy production and specifically of district heating production.

\subsubsection{Life Cycle Inventory}

The inventory for the LCA resulted in the amount of construction materials added and removed during the renovation and maintenance (Table 3), the amount of energy required during the use of the building (Table 4), and the environmental impacts resulting from the processing outside the building site (i.e., energy production, construction material production and waste treatment).

Table 3. Construction material quantities required for the renovation work and maintenance of the building. Materials and amounts are similar in the two renovation cases, except for the components in italic.

\begin{tabular}{|c|c|c|c|}
\hline Component & Material & Amount for the Renovation & Amount for Maintenance \\
\hline \multicolumn{4}{|l|}{ Removed material } \\
\hline Roof & Clay & $38,600 \mathrm{~kg}$ & $-a$ \\
\hline Façade & Asbestos & $14,100 \mathrm{~kg}$ & $-a$ \\
\hline Windows & Miscellaneous & $11,100 \mathrm{~kg}$ & $-a$ \\
\hline Others & Miscellaneous & $4900 \mathrm{~kg}$ & $-a$ \\
\hline \multicolumn{4}{|l|}{ Roof } \\
\hline Tiles & Clay & $35,640 \mathrm{~kg}$ & $35,640 \mathrm{~kg}$ \\
\hline Insulation & Phenolic foam & $4800 \mathrm{~kg}$ & $-b$ \\
\hline Roofing felt & Polypropylene film & $210 \mathrm{~kg}$ & $210 \mathrm{~kg}$ \\
\hline New framing elements & Pine wood & $13,280 \mathrm{~kg}$ & $-b^{O}$ \\
\hline Walkway and snow fences & Steel & $1730 \mathrm{~kg}$ & $1730 \mathrm{~kg}$ \\
\hline \multicolumn{4}{|l|}{ Façade } \\
\hline Insulation, 1st floor & Expanded polystyrene & $2700 \mathrm{~kg}$ & $-b$ \\
\hline Cladding material, 1 st floor & Plaster & $22,500 \mathrm{~kg}$ & $22,500 \mathrm{~kg}$ \\
\hline Insulation, other floors & Glass wool & $4400 \mathrm{~kg}$ & $-\mathrm{b}$ \\
\hline \multirow{2}{*}{ Cladding material, other floors } & Pine wood * & $18,560 \mathrm{~kg} *$ & $18,560 \mathrm{~kg}$ * \\
\hline & Fibre-cement boards ** & $34,380 \mathrm{~kg}^{* *}$ & $34,380 \mathrm{~kg} * *$ \\
\hline \multicolumn{4}{|l|}{ Windows and doors } \\
\hline Windows & $\begin{array}{l}\text { Wooden and aluminium } \\
\text { framed 3-pane windows }\end{array}$ & $12,090 \mathrm{~kg}$ & $12,090 \mathrm{~kg}$ \\
\hline Entrance door & Pine wood and 3-pane glazing & $600 \mathrm{~kg}$ & $600 \mathrm{~kg}$ \\
\hline Basement door & Oak and aluminium & $100 \mathrm{~kg}$ & $100 \mathrm{~kg}$ \\
\hline
\end{tabular}

${ }^{*}$ Real renovation, with wooden façade. ${ }^{* *}$ Alternative renovation, with fibre-cement boards. ${ }^{a}$ Not applicable. ${ }^{b}$ No replacement during maintenance.

The data in Table 4 show a significant difference between the energy consumption calculated by the external consultant using numerical energy simulations and the measured value over 2 years after renovation. The expected energy reduction falls from $34 \%$ of reduction compared to pre-renovation level, according to the simulation, to only $12 \%$ based on real consumptions. 
Table 4. Estimated energy use of the building.

\begin{tabular}{cccc}
\hline & $\begin{array}{c}\text { Before the } \\
\text { Renovation }\end{array}$ & $\begin{array}{c}\text { After the } \\
\text { Renovation-Thermal } \\
\text { Simulation }\end{array}$ & $\begin{array}{c}\text { After the Renovation- } \\
\text { Measured }\end{array}$ \\
\hline Heating $\left(H_{e}+W_{e}\right)$ & $412 \mathrm{MWh} /$ year & $274 \mathrm{MWh} /$ year & $361 \mathrm{MWh} /$ year \\
\hline Electricity $($ Elec $)$ & $4 \mathrm{MWh} /$ year & $2 \mathrm{MWh} /$ year & $7 \mathrm{MWh} /$ year \\
\hline
\end{tabular}

\subsubsection{Environmental Impact Related to Construction Materials of the Renovation}

Figure 4 summarises the results from the LCA of the renovation, except for the impact from the building's energy use, expressed in total required primary energy and the GWP of each stage of the life cycle of the products. For both the real renovation and the alternative renovation, the total impact due to the addition and replacement of materials is almost equally divided into the three major retrofit measures (roof/façade/windows and doors) and is mainly related to the production of materials for the renovation and the maintenance of the building. The end-of-life treatment of the materials added for the renovation is also significant for the GWP impact related to construction materials, mainly because of insulation materials' end-of life treatment. The construction waste during renovation is almost negligible.
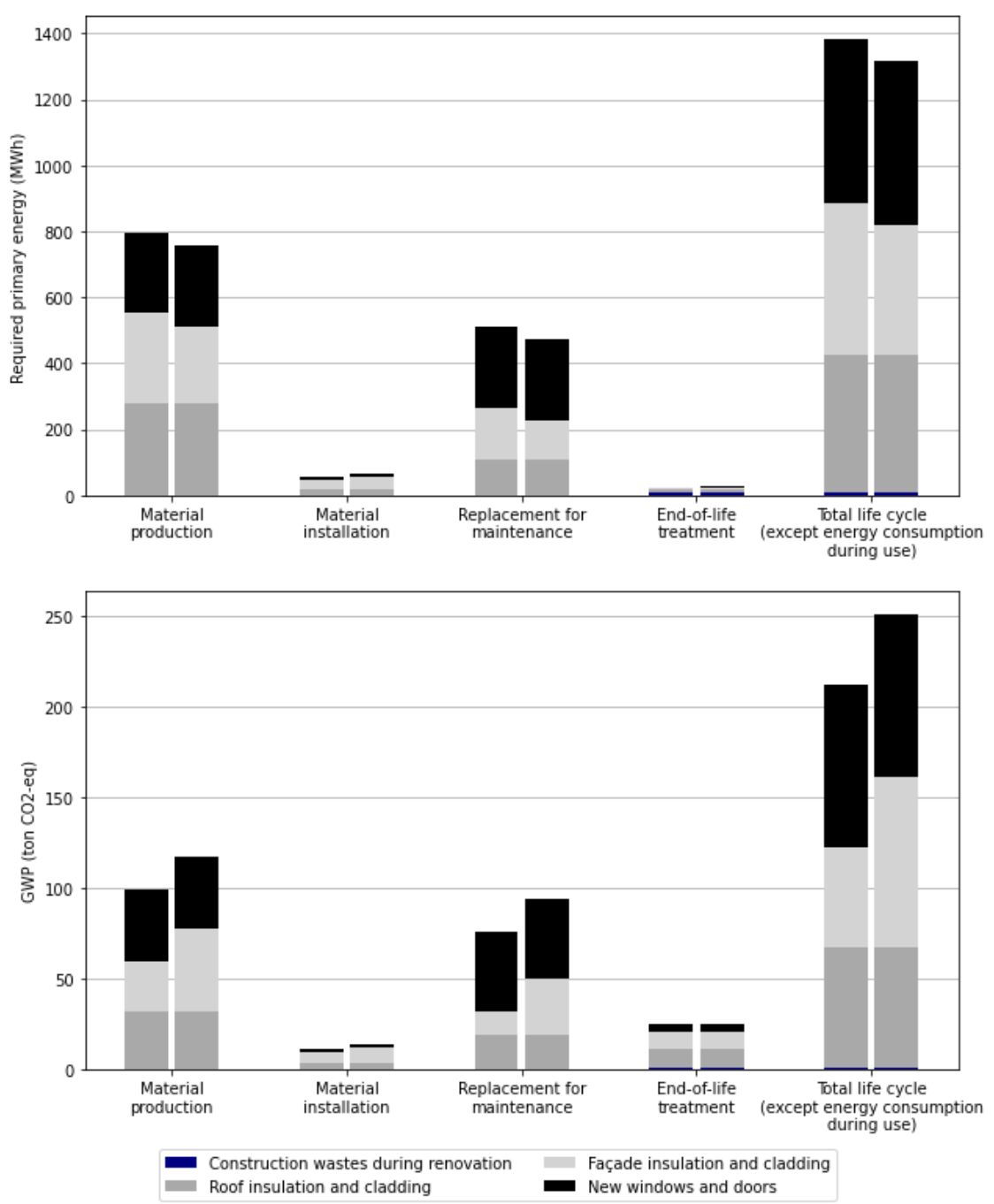

Figure 4. GWP impact and required primary energy related to construction materials over the life cycle of the building in the case of the real renovation (top) and the alternative renovation (bottom). 


\subsubsection{Economic and Environmental Payback Times}

Payback times and embodied impacts for the different renovation measures, separately and combined, are presented in Table 5 . With the estimation based on the calculated energy savings, the renovation gives satisfying results, with a primary energy payback time of 6.5 years and a carbon payback time of 7 years. When each energy saving measure is considered separately, the replacement of windows and the insulation of the roof are estimated as having shorter payback times than the façade insulation ( 24.2 and 22 years for primary energy and carbon respectively).

The environmental payback time increases notably when using the measured energy data, rising from 6.5 to 24.5 years for primary energy, and from 7.0 to 24.7 years for GWP (Table 5). Those values are still lower than 50 years-the expected lifespan of the renovated building.

Table 5. Payback times for the renovation work.

\begin{tabular}{|c|c|c|c|c|c|c|c|}
\hline $\begin{array}{c}\text { Type of } \\
\text { Energy Data }\end{array}$ & $\begin{array}{l}\text { Renovation } \\
\text { Scenario }\end{array}$ & $\begin{array}{l}\text { Energy } \\
\text { Saving } \\
\text { (MWh } \\
\text { pe/Year) }\end{array}$ & $\begin{array}{c}\text { EE } \\
\text { (MWh pe) }\end{array}$ & $\begin{array}{l}\text { PBT }_{\text {energy }} \\
\text { (Years) }\end{array}$ & $\begin{array}{c}\mathrm{EC} \\
\left(\operatorname{ton} \mathrm{CO}_{2}-\mathrm{eq}\right)\end{array}$ & $\begin{array}{l}\text { PBT }_{\text {carbon }} \\
\text { (Years) }\end{array}$ & $\begin{array}{l}\text { PBT }_{\text {economic }} \\
\text { (Years) }\end{array}$ \\
\hline \multirow{4}{*}{$\begin{array}{l}\text { Energy savings } \\
\text { estimated with } \\
\text { a thermal } \\
\text { simulation }\end{array}$} & Real renovation & 131 & 857 & 6.5 & 112 & 7.0 & 41 \\
\hline & $\begin{array}{l}\text { - Insulation of } \\
\text { the roof }\end{array}$ & 65.6 & 300 & 4.5 & 36.7 & 4.5 & - \\
\hline & $\begin{array}{l}\text { - Insulation of } \\
\text { the façade }\end{array}$ & 12.5 & 303 & 24.2 & 33.7 & 22.0 & - \\
\hline & $\begin{array}{l}\text { Replacement } \\
\text { of windows } \\
\text { and doors }\end{array}$ & 51.4 & 255 & 5.0 & 41.7 & 6.6 & - \\
\hline \multirow{2}{*}{$\begin{array}{l}\text { Energy savings } \\
\text { estimated with } \\
\text { energy bills }\end{array}$} & Real renovation & 35.0 & 857 & 24.5 * & 112 & $24.7 *$ & 67 \\
\hline & $\begin{array}{l}\text { Alternative } \\
\text { renovation }\end{array}$ & 35.0 & 829 & 23.7 * & 132 & $29.2^{* *}$ & - \\
\hline
\end{tabular}

EE: embodied energy, EC: embodied carbon, pe: primary energy, PBTenergy, PBTcarbon, PBTeconomic: payback time for the cumulated primary energy consumption, GWP and economic investments respectively. Due to the replacement of some materials for maintenance 30 and 40 years after the renovation, ${ }^{*}$ the cumulated impact of the renovation exceeds the one of the building without any refurbishment work, but this difference is offset within 4 years; ** the cumulated impact of the renovation exceeds the one of the building without any refurbishment work and is not offset within the building lifespan of 50 years considered in this study.

Regarding economic investment, using the measured energy consumption data increases the payback of the renovation from 41 to 67 years (Table 5), which means that there is no payback for the investment before a new renovation is required.

\subsubsection{Difference in the LCA Results between the Real and Alternative Renovation}

Fibre-cement boards were the initial preferred façade choice for the property owners with less expected maintenance. According to recommendations addressed to Swedish property owners [43], if wooden panels are repainted every ten years, the lifetime of the façade is 40 years, compared to the expected average lifetime of 30 years for fibrecement boards.

The embodied primary energy for the fibre-cement boards necessary to cover a given façade area is $27 \%$ lower than for the wooden panels necessary to cover the same façade area, but the embodied carbon is as much as $290 \%$ higher. This leads to a decrease (respectively increase) in the required primary energy (respectively GWP impact) related to the production of the material required for the alternative renovation and its maintenance (Figure 4), which explains the lower embodied energy, but the higher embodied carbon for the two different façade scenarios (Table 5).

If the same energy savings could be expected as in the actual renovation, the choice of fibre-cement board would have led to a slightly lower energy payback time of 23.7 years, but an increased carbon payback time of 29.2 years (Table 5). The increase in GWP related 
to the production of fibre-cement boards compared to wooden panels is enough to provide a resulting cumulated impact after 50 years of use slightly higher (2042 tons $\mathrm{CO}_{2}$-eq, $+0.4 \%$ ) than the building without any refurbishment or maintenance involving new construction material (2033 tons $\mathrm{CO}_{2}$-eq).

\subsubsection{Uncertainty Analysis}

The operational energy use of the building represents $92 \%$ of the cumulated primary energy and $89 \%$ of the GWP impact. The environmental impact of delivered energy, and especially delivered district heating, has thus had a great influence on the results. In order to estimate the potential impact from uncertainties in the energy environmental data on the results, an estimation of payback times was made using different sources of environmental data for distributed energy.

No value for the efficiency of Swedish energy and heat production were found other than the one provided by Liljenström et al. [5]. For district heating of the city of Gothenburg, the supplier reported a yearly estimation of the GWP for their provided district heat of between 0.059 and $0.079 \mathrm{~kg} \mathrm{CO}$-eq $/ \mathrm{kWh}$, with $0.073 \mathrm{~kg} \mathrm{CO}_{2}$-eq $/ \mathrm{kWh}$ in 2018 [49]. With respect to the Swedish national average, district heating has been evaluated as generating between $0.097 \mathrm{~kg} \mathrm{CO}$-eq $/ \mathrm{kWh}$ by Liljenström et al. [5] and $0.14 \mathrm{~kg} \mathrm{CO}$-eq $/ \mathrm{kWh}$ by Bengt Dahlgren AB [50].

Figure 5 shows the estimated carbon payback time for the renovation calculated with values for the district heating between 0.059 and $0.14 \mathrm{~kg} \mathrm{CO}_{2}-\mathrm{eq} / \mathrm{kWh}$. The results show that the carbon payback time of the renovation then varies from 17 years using the Swedish national average estimation [50], to 43 years using the lowest environmental data achieved from Göteborg Energi [49].

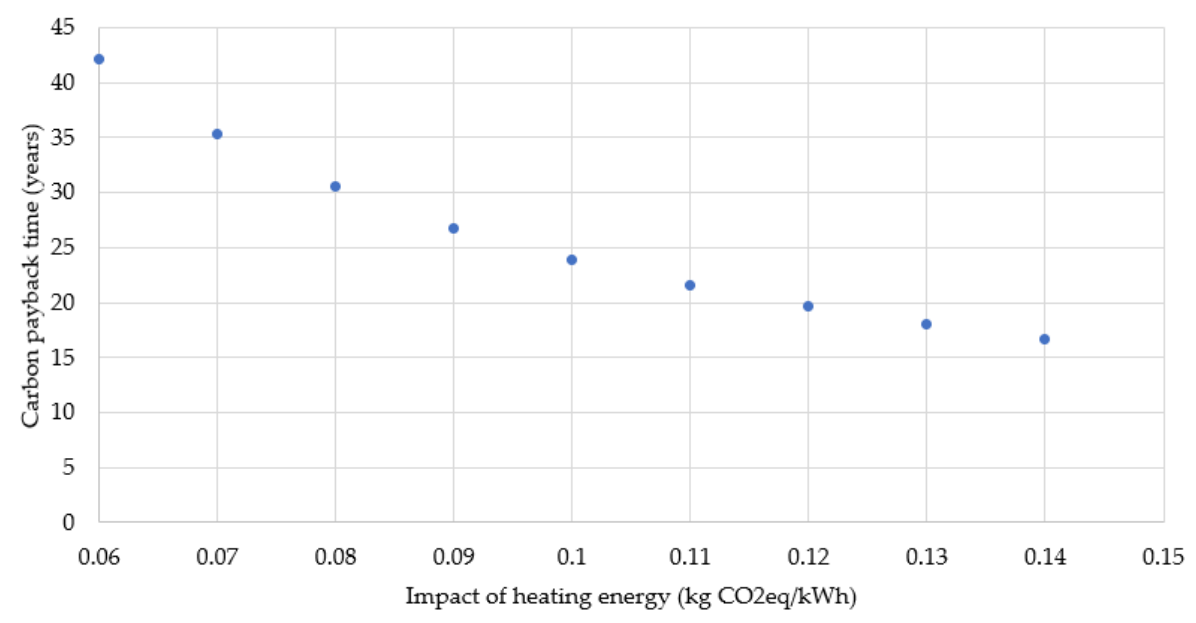

Figure 5. Evolution of the carbon payback time of the renovation with the GWP of district heating provided to the studied building.

\subsection{Results from the Questionnaire and Interviews with the Tenants}

Results from the questionnaire show that the tenants in the area are generally satisfied with their home. The closeness to nature and recreational areas, together with a calm and safe living environment, and the low rents, have attracted them to the area. Among the negative characteristics, respondents living in the not-yet renovated buildings mention "old buildings" and deficient ventilation. What the tenants expect from the up-coming renovation is: better indoor temperature and less draught (17\% respective $15 \%$ of the responses), followed by a better sound environment (12\%), an improved outdoor environment (12\%) and improved aesthetics of the buildings (12\%).

A question was posed about the cultural historical value that the tenants attribute to their building. The tenants living in the case building with the recreated wooden façade attributed to their building a mean value of 3.53 on a scale from zero to five, where five 
indicated the highest value. Tenants living in the not-yet renovated buildings, still with the fibre-cement boards from the 1970s, attributed to their building the mean value 3.0 on the same scale. The respondents were then asked which materials and characteristics, in a predefined list of building parts, they attributed the highest cultural historical value on the exterior to the building (Figure 6, left) and inside their apartment (Figure 6, right). The respondents could select several options. With respect to exterior values, windows, facades and the building's situation in the urban landscape were among the highest valued parts. To be noted, 25 of the respondents ticked "no opinion" and five respondents ticked "other". Of these five who answered "other", two respondents wrote "barnrikehus", indicating that they highly value the social history of the building, and two made general comments on the need for renovation. Regarding interior values, interior doors, flooring, windows and radiators scored highly, but so did "no opinion". Seven respondents ticked "other" and, out of these, three mentioned the well-designed and functional built-in closets, two respondents mentioned the internal floor and windows, which already were pre-defined options, and one mentioned the high ceiling height as an appreciated value.

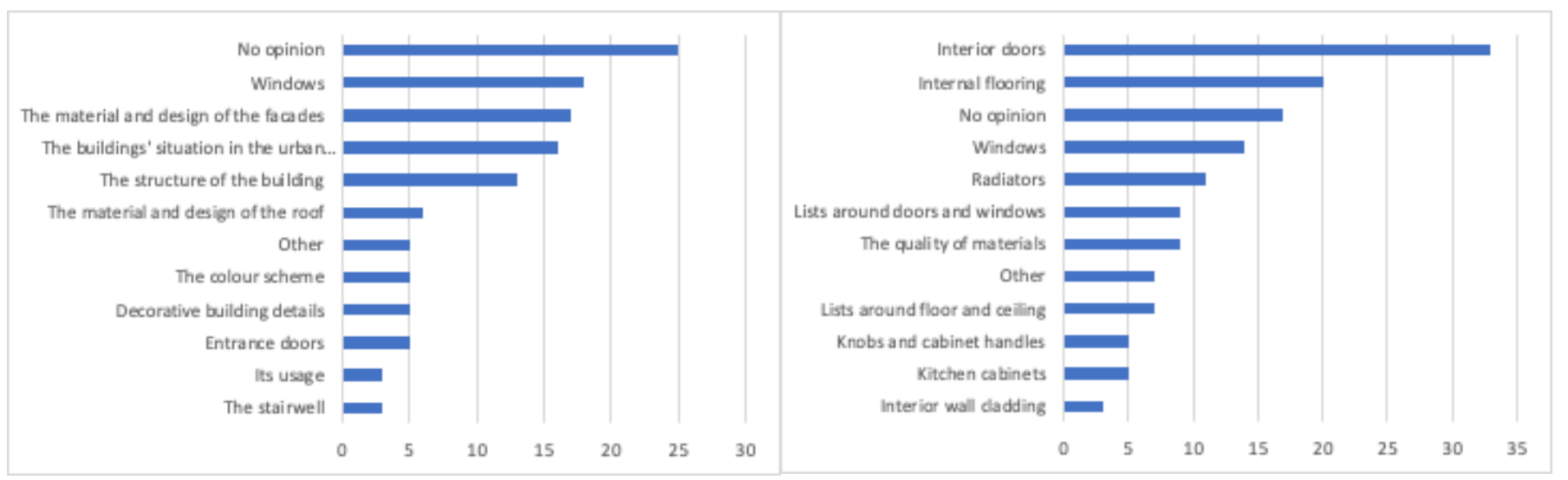

Figure 6. Building parts, materials and characteristics that the respondents of the questionnaire attribute the highest cultural historical value, on the exterior of the building (left) and inside the apartment (right).

The interviews with six tenants show that the buildings' age and history is important for all of them. They find it important that the buildings have a social history as "barnrikehus" for families with many children, and they experience that the buildings have a soul. Appreciated details of the buildings are the windows, the wooden floors and the imperfectness, the crooked and winding walls and floors that brings life into the home.

As seen in Figure 6, the results to the questionnaire show that windows are perceived as an important element for the cultural value of a building. Seven of the respondents of the questionnaire comment on their dissatisfaction with the new chosen widows in the case building, with the false mullion. A "ridiculous stick", as one respondent calls it. The interviews confirm this dissatisfaction with the chosen windows found in the questionnaire. The interviewees think that the newly recreated wooden façade on the case building results in an aesthetic improvement of the area, but they dislike the chosen windows. Two of the tenants living in a not-yet renovated building block have very strong reactions against the new windows and would prefer to keep the old ones, even though this means less indoor comfort and more draught. They value the history and the aesthetics of the old windows more than comfort, and they argue that they prefer keeping the old windows and having a lower perceived indoor temperature, rather than getting new windows and a higher perceived indoor temperature. One of the two tenants declares that she would move out if she would get the same new windows as in the case building. The only younger interviewee expresses a different view. She thinks that even though she appreciates the aesthetics and history of the older windows, she would compromise this in favour of a better indoor climate and less draught. She is the only one of the six interviewees that finds it reasonable to replace the windows to save the environment. 
The results from the questionnaire and the interviews must be interpreted with some caution. The response rate for the questionnaire can be considered in a normal range, in a time of decreasing interest to take part in surveys [51], but the representativeness of the expressed views could be biased. The persons that were able to meet us for an interview were in large majority retired persons, and only one younger tenant on a longer sick leave. It could be that the over-representation of older respondents does not represent all residents in the studied buildings.

\section{Discussion}

In this paper, several different assessments have been performed to discuss the environmental, economic, social and cultural value of an energy renovation in which a wooden façade of a previously renovated and disfigured pre-war multi-residential building was recreated. The energy, carbon and financial payback times have been estimated. The motives and decisions behind the renovation, as well as the tenants' experience of the renovation and recreation, have been studied. A comparison of the environmental payback times between the wooden façade and an alternative and more conventional renovation, with low maintenance fibre-cement boards, was carried out to discuss the environmental consequences of the recreated façade. The difficulties of retrieving environmental data from openly accessible sources were also discussed, supported by an uncertainty analysis of environmental data for district heating production.

\subsection{Benefits from the Real Renovation in Terms of Energy and Carbon Savings}

The calculated energy savings from the retrofit measures were estimated to a $37 \%$ reduction. Using the real monitored energy use shows that only a $12 \%$ reduction was factually achieved. This result aligns with an earlier study which estimates the general potential of energy reduction in Swedish housing from upgraded windows and U-values to be around $14 \%$ [52]. However, $12 \%$ of energy reduction does not correspond to the high-level Swedish national goals for energy efficiency through renovation.

The performance gap between expected and monitored energy performance from renovation has been discussed in previous studies [53]. The difference can be explained by an inaccurate prediction of engineering system performance and by users' behaviour [54]. To reach higher levels of energy efficiency in renovation, the improvement of the building envelope alone is not sufficient and needs to be combined with other measures, such as the heat recovery from air ventilation [55]. The property owner has logged the indoor temperature in several of its buildings and found in general higher temperatures in the renovated building than in the unrenovated adjacent buildings. In some apartments, the temperature was found to be above 20 to 23 degrees Celsius, which is recommended by the Public Health Agency of Sweden [56] and the 21 degrees Celsius used for energy calculations according to Swedish Building Regulations [57]. As shown by Mata et al. [52], the limitation of indoor temperature to $20^{\circ} \mathrm{C}$ is a measure with great potential to impact the energy and carbon impact reduction for the Swedish residential building stock. Accordingly, the addition of heat control sensors could be a measure to consider.

The results from the LCA study show a favourable environmental return on investment in terms of cumulated primary energy use and GWP, lower than the intended life span of the renovation. When using the calculated savings for operational energy use, the resulting payback times for the renovation align with previous studies of renovation of post-war dwellings both in terms of primary energy (below 4 years according to Dodoo et al. [58]), and in term of GWP (below 7 or 8 years according to Mohammadpourkarbasi and Sharples [26] and Erlandsson and Levin [59] respectively). However, the expected environmental payback times in this study are multiplied by 3.5 due to the difference between the calculated energy savings and the monitored energy use.

Payback times for the renovation are estimated without consideration of the possible additional impact generated by the maintenance with replacement of the construction materials. When considering this replacement of materials, the cumulated environmental 
impact of the renovated building over its 50-year lifetime exceeds the impact that would have been generated by leaving the building in its state before the renovation (Figure 7). The renovation is estimated to be paid back 41 years after the renovation for what concerns cumulated primary energy and 44 years for GWP. Those payback periods are much higher than what is referred to in previous studies, i.e., a payback time lower than 8-10 years for a complete renovation $[22,25,58,60-62]$, and is in fact closer to the estimated payback times for individual measures on the building envelope from Asdrubali et al. [60] (energy payback time of 31 years) and from Beccali et al. [61] (energy payback time between 21 and 43 years and carbon payback time between 27 and 35 years depending on the renovation measure).
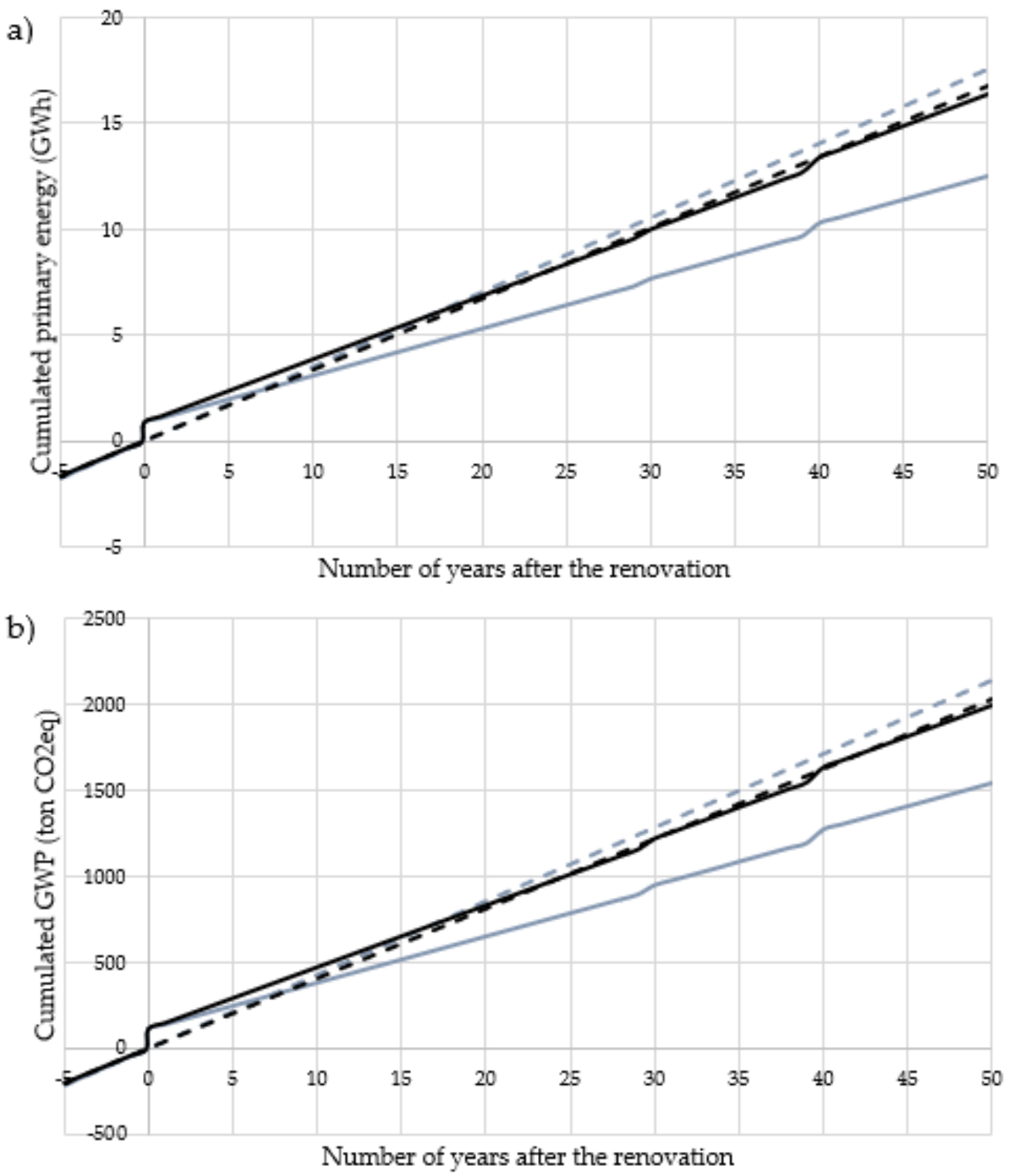

\footnotetext{
- - -Non-renovated building with calculated energy consumption

With calculated energy savings

- - Non-renovated building with measured energy consumption

With measured energy savings
}

Figure 7. Cumulative impact of the real renovation over time (a) for primary energy and (b) for GWP with calculated and measured energy savings. 
From a financial perspective, the renovation has a long pay back (41 years based on the calculated energy use and 67 years for the measured), and is therefore expected to be unprofitable for the owner. The payback will be even longer when including costs for maintenance, which will be necessary further on, such as the painting of the façade.

\subsection{Environmental Impact Related to Architecture, Heritage and Thermal Comfort}

Besides environmental and economic aspects, there are other benefits from the renovation. First, the thermal comfort has been improved for the tenants, and this has been achieved with only a low rent increase. Second, the recreated façade has improved the aesthetics of the building, and the appreciation of this among the tenants has been captured in our questionnaire and interviews, and has been confirmed by the property owner in their contact with the tenants. The aesthetic and cultural improvement of the building from the recreated façade has unfortunately been compromised by the choice of windows. This mistake with the windows seems to have been recognised by the property owner. In a new phase of renovations, finalised in 2018 in the same housing area, the façade has been recreated in the same way as the case study building, but instead of pivot-hinged windows, side-hinged windows of the same typology as the original have been used (Figure 8).

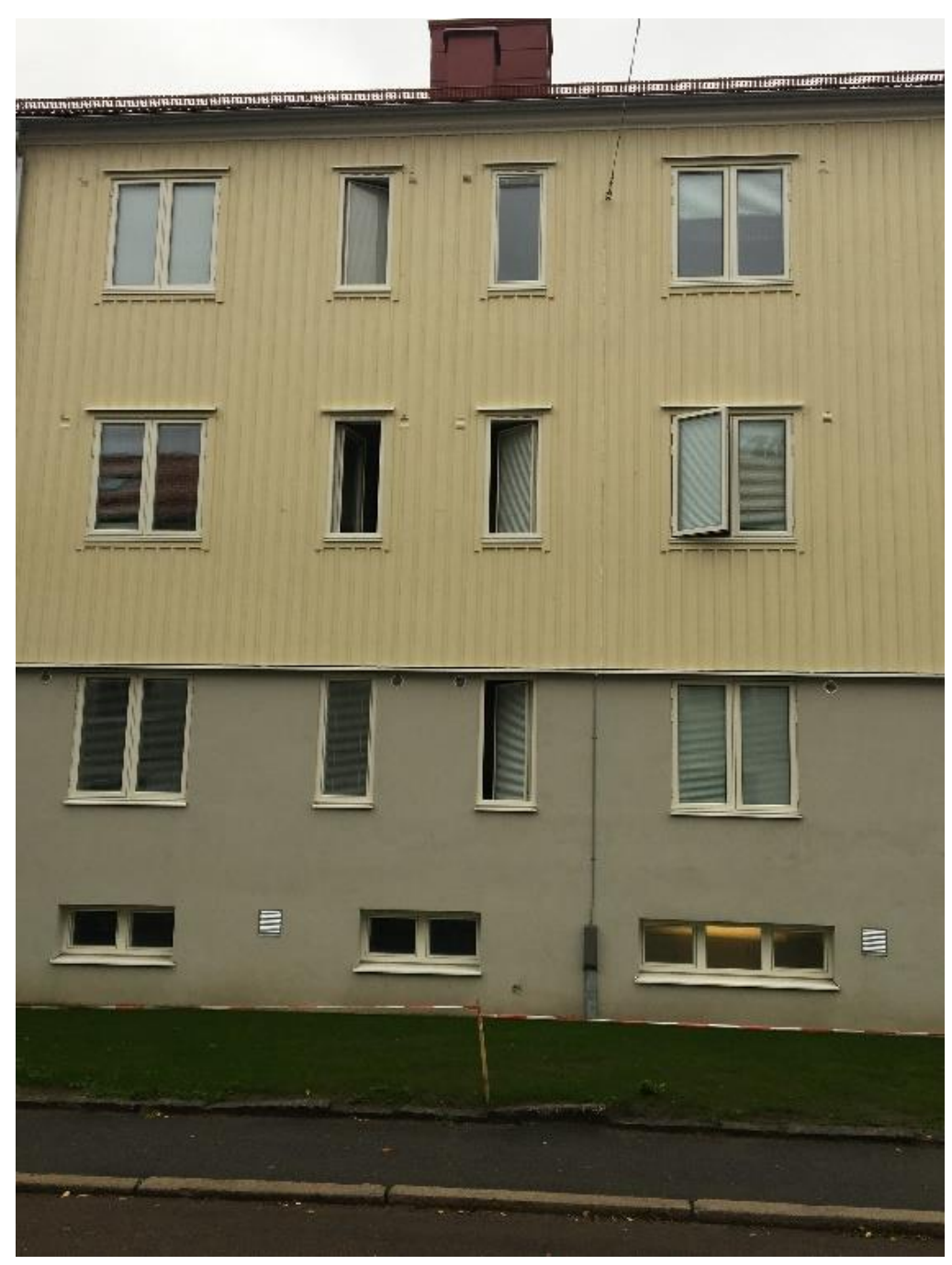

Figure 8. Side-hinged windows in a new phase of renovations in the area, which to a higher degree resemble the original windows and façades. Photo P. Femenias 2018.

The choice to recreate a wooden façade instead of using fibre-cement boards, a more commonly used façade material, can be justified based on the results from the environ- 
mental LCA. The wooden façade has a better environmental performance in term of GWP $(-15 \%$, see Table 5). Regarding primary energy requirements, the wooden façade scores higher, but the difference is marginal $(+3 \%)$, and the wooden façade remains profitable from an environmental point of view.

The recreation of the façade on the case study building is not a historic refurbishment. The aesthetic differs from the original façade and architecture of this specific building, although the same type of façade can be found on other buildings in the neighbourhood. The impact on the authenticity on an individual building level, and the possible large-scale effect on the historic environment from similar non-authentic recreations, is not discussed in this paper. However, non-authentic façade recreations could have large consequences for the authenticity of the local historic environment. This phenomenon should be recognised and discussed among planners, architects, and antiquarians.

\subsection{Uncertainties from Environmental Data}

The environmental LCA results from the study are sensitive to the data used for the calculations. A main challenge was to find accessible relevant environmental data, with an estimation of the primary energy needed and the GWP for each life cycle phase of the new construction materials. Environmental data specific to a product differ with the location of the manufacturing place and the age of data, as the energy mix, technology for production and need of transportation vary over time and location. EPDs provide data specific to a product and manufacturer, but were available for only three construction materials for this case study. Accessible average data representative of a country are gathered in databases such as Ökobaudat for Germany [41] and Ökobilanzdaten im Baubereich for Switzerland [42], but representative data for Sweden were hardly found. There is unfortunately no information reported on the variance of environmental data in the data sources used. As pointed out by Heijungs et al. [63], this is often the case for environmental data due to the limited access to data and resources to develop environmental datasets.

As stated by Vilches et al. [22], LCA methodology can be implemented differently from case to case, especially because such an assessment relies on assumptions for the future of the building itself and the construction materials for the renovation. As an example, an evolution of the Swedish energy mix over time was not considered. Previous studies showed that current scenarios for the future energy mix do not have a significant impact on the resulting payback time for a renovation, with variations of several months [60]. A constant yearly energy consumption during the use of the building, based on the measured energy use during two years after the renovation, was also assumed, disregarding the possible evolution of energy efficiency with the age of the building. Finally, another main assumption for this study was that the maintenance other than the replacement of added materials during the renovation would not have a significant impact on the total cumulative environmental impact. This corresponds with the minor repairs studied by Grant et al. [64], which have been found to have a negligible impact compared to major replacements.

Choosing to study a longer service life of the building opens a much higher risk of large uncertainties in the results. Besides the evolution of the energy mix or the energy performance mentioned above, the modelling performed in this study is unable to take into account the technology development influencing the environmental impact due to materials for maintenance or maintenance techniques, nor unexpected events in the life of the building.

Finally, variations in openly available data for GWP of the district heating production highly affect the results of the study and the carbon payback times, as shown by the uncertainty analysis. This sensitivity enhances the importance of providing accessible data for life cycle environmental assessment. As stated by Francart et al. [7], municipalities should provide such resources as local planning actors to facilitate such assessments or ask national authorities to provide tools and data. 


\section{Conclusions}

In this study, the benefits from an energy renovation and the recreation of aesthetic and cultural values of a wooden façade that was lost in a previous renovation have been investigated from three different perspectives: (1) the environmental impact of the renovation with an LCA, (2) the financial payback time, and (3) the satisfaction among tenants using a questionnaire and interview study. The results contribute to holistic studies of sustainable renovation by providing a case of a pre-war housing, a part of the housing stock which has been less studied and targeted by LCA studies on building renovations. The study also adds a new perspective to studies of energy renovations by including an assessment of perceived aesthetic and cultural value.

The environmental LCA results show that the renovation with the recreated façade is beneficial for the environment, both in terms of primary energy consumption and GWP, as the payback times are lower than the expected lifespan of the renovation, which is estimated to be 50 years ( 24.5 years for cumulated primary energy and 24.7 years for GWP). Compared to a renovation scenario with fibre-cement boards on the façade, representing a common choice of façade material for renovation and new constructions in Sweden, the choice of recreating a wooden façade led to a lower carbon payback time and to a marginal increase of the energy payback time. In contrast, the direct economic benefits are limited. A first estimation of the payback time results in a return on investment of 67 years, which is beyond the life-expectancy of the renovation. However, there are other benefits in terms of increased quality of life for the tenants, through a better thermal comfort and a more aesthetic living environment. Results from the questionnaire and the interviews with the tenants indicate that tenants do value the improved aesthetics of their living environment.

The fact that the recreation of architectural values can be made without compromising the environmental benefit from the energy renovation can have relevance for the current political emphasis on cultural value and heritage for sustainable development. The importance of design and cultural aspects are highlighted in national, as well as international, policies $[15,16]$, and was recently given a major new push when the President of the European Community, Ursula von der Leyen, set up the initiative 'New European Bauhaus' to create sustainable, beautiful and inclusive living environments [65].

The results from the study can be used as input for decision-making among propertyowners, and authorities working with planning and building permits and with the preservation of historic environments, locally and nationally. In light of the anticipated largescale renovations of multi-residential buildings to modernise older stocks and meet demand driven by energy goals and the energy renovation wave initiated by the European Union [63], holistic approaches to energy renovation that also include assessments of the larger environmental benefit as well as other values, are needed. Holistic approaches refer to the inclusion of life-cycle assessments, but also economic, social and cultural perspectives. The case study in this paper represents a special situation where previously lost values are recreated. However, there are many buildings which have been disfigured in similar ways through earlier energy renovation and recreations and that can be anticipated in Sweden but also abroad [33]. This study provides information that can be useful in the decision-making of such projects, but also generally in decision-making for energy renovation. The results from a comparison of the wooden façade to a fibre-cement board façade are applicable to other types of renovation, and the results from the study of appreciation of heritage values among tenants should be applicable in all renovations where preservation of cultural historical values is dealt with.

Finally, the study shows that access to suitable environmental LCA data is limited and might compromise the results of environmental assessments. The carbon payback time of the studied case varies between 17 and 43 years depending on the data found in different sources for the GWP associated with district heating production, showing the importance of the choice of energy sources on the environmental life cycle performance of the building. 
Supplementary Materials: The following are available online at https://www.mdpi.com/article/10 .3390/heritage4040201/s1, Document S1: Additional information and data.

Author Contributions: A.J.: Conceptualisation, Methodology, Investigation, Formal Analysis, Writing-Original draft financial and environmental assessment and discussion, Review and Editing. P.F.: Conceptualisation, Writing-Original draft introduction and tenant study, Review and Editing. Funding Acquisition and Project Administration. L.T.: Comments on Conceptualisation and Methodology. Writing: Review and Editing. P.J.: Comments on Conceptualisation and Methodology. Writing: Review and Editing. P.W.: Comments on Conceptualisation and Methodology. Writing: Review and Editing. All authors have read and agreed to the published version of the manuscript.

Funding: The study was funded by the Swedish Energy Agency through the Programme Save \& Preserve, project number 40461-1 and project title "Re-renovation possibilities to improve energy efficiency and recreate cultural values".

Institutional Review Board Statement: Not applicable.

Informed Consent Statement: Not applicable.

Data Availability Statement: The data presented in this study are available on request from the corresponding author. The data are not publicly available due to privacy reasons.

Acknowledgments: We thank Bostads AB Poseidon and Calles Bygg for access to data on the properties and the renovation.

Conflicts of Interest: The authors declare no conflict of interest.

\section{References}

1. European Commission. The Energy Performance of Buildings. Available online: https://ec.europa.eu/energy/en/topics/ energy-efficiency/energy-performance-of-buildings/overview (accessed on 10 October 2019).

2. Eurostat Air Emissions Accounts by NACE Rev. 2 Activity. Available online: https://ec.europa.eu/eurostat/web/productsdatasets/-/env_ac_ainah_r2 (accessed on 15 October 2019).

3. Swedish Government Bill. Nationellt Program för Energieffektivisering och Energismart Byggande; Regeringens Proposition 2005/06:145; Swedish Government: Stockholm, Sweden, 2006. Available online: https://www.riksdagen.se/sv/dokumentlagar/dokument/proposition/nationellt-program-for-energieffektivisering-och_GT03145/html (accessed on 15 October 2021).

4. Regeringens Infrastrukturdepartement. Sveriges Tredje Nationellastrategi för Energieffektiviserande Renovering; Swedish Government: Stockholm, Sweden, 2020.

5. Liljenström, C.; Malmqvist, T.; Erlandsson, M.; Fredén, J.; Adolfsson, I.; Larsson, G.; Brogren, M. Byggandets KlimatpåverkanLivscyckelberäkning av Klimatpåverkan och Energianvändning för ett Nyproducerat Energieffektivt Flerbostadshus i Betong; IVL Svenska Miljöinstitutet: Stockholm, Sweden, 2015.

6. Birgisdottir, H.; Moncaster, A.; Wiberg, A.H.; Chae, C.; Yokoyama, K.; Balouktsi, M.; Seo, S.; Oka, T.; Lützkendorf, T.; Malmqvist, T. IEA EBC annex 57 'evaluation of embodied energy and $\mathrm{CO}_{2 \mathrm{eq}}$ for building construction'. Energy Build. 2017, 154, 72-80. [CrossRef]

7. Francart, N.; Larsson, M.; Malmqvist, T.; Erlandsson, M.; Florell, J. Requirements set by Swedish municipalities to promote construction with low climate change impact. J. Clean. Prod. 2019, 208, 117-131. [CrossRef]

8. Boverket. Klimatdeklarationer av Byggnader: Förslag på Metoder och Regler; Boverket: Karlskrona, Sweden, 2018.

9. Bygg-Ochanläggningssektorn/Constructionsector Färdplan för Fossilfri Konkurrenskraft; Action Plan for Fossile Free Competitiveness; Fossilfritt Sverige: Stockholm, Sweden, 2018.

10. SCB. Bostadsbestånd Statistic. Available online: https:/ /scb.se/ (accessed on 25 March 2020).

11. PBL. Plan och Bygglag; Swedish Government: Stockholm, Sweden, 2010.

12. Malafry, M. Skyddet av kulturvärden i omställningen till ett koldioxidneutralt samhälle:-En studie av det rättsliga skyddet av kulturvärden mot installation av solceller i plan- och bygglagen respektive kulturmiljölagen. Nord. Miljörättslig Tidskr. 2021, 2020, 77-98.

13. Jensen, P.A.; Maslesa, E.; Berg, J.B.; Thuesen, C. 10 questions concerning sustainable building renovation. Build. Environ. 2018, 143, 130-137. [CrossRef]

14. Mjörnell, K.; Femenías, P.; Annadotter, K. Renovation Strategies for Multi-Residential Buildings from the Record Years in Sweden-Profit-Driven or Socioeconomically Responsible? Sustainability 2019, 11, 6988. [CrossRef]

15. UNESCO. Culture for the 2030 Agenda; UNESCO: Paris, France, 2018.

16. Swedish Government. Regeringens Proposition 2017/18:110. Politik för Gestaltad Livsmiljö 2018; Swedish Government: Stockholm, Sweden, 2018.

17. Boverket Kulturhistoriskt Värdefull Bebyggelse. Delmål 2-Underlags_Rapport Till Fördjupad Utvärdering av Miljömålsarbetet; Boverket: Karlskrona, Sweden, 2003. 
18. Webb, A.L. Energy retrofits in historic and traditional buildings: A review of problems and methods. Renew. Sustain. Energy Rev. 2017, 77, 748-759. [CrossRef]

19. Fouseki, K.; Cassar, M. Energy Efficiency in Heritage Buildings-Future Challenges and Research Needs. Hist. Environ. Policy Pract. 2014, 5, 95-100. [CrossRef]

20. CEN. Conservation of Cultural Heritage-Guidelines for Improving the Energy Performance of Historic Buildings; European Committee for Standardization (CEN): Brussels, Belgium, 2017.

21. Assefa, G.; Ambler, C. To demolish or not to demolish: Life cycle consideration of repurposing buildings. Sustain. Cities Soc. 2017, 28, 146-153. [CrossRef]

22. Vilches, A.; Garcia-Martinez, A.; Sanchez-Montañes, B. Life cycle assessment (LCA) of building refurbishment: A literature review. Energy Build. 2017, 135, 286-301. [CrossRef]

23. Foster, G.; Kreinin, H. A review of environmental impact indicators of cultural heritage buildings: A circular economy perspective. Environ. Res. Lett. 2020, 15, 043003. [CrossRef]

24. Foster, G.; Kreinin, H.; Stagl, S. The future of circular environmental impact indicators for cultural heritage buildings in Europe. Environ. Sci. Eur. 2020, 32, 141. [CrossRef]

25. Ardente, F.; Beccali, M.; Cellura, M.; Mistretta, M. Energy and environmental benefits in public buildings as a result of retrofit actions. Renew. Sustain. Energy Rev. 2011, 15, 460-470. [CrossRef]

26. Mohammadpourkarbasi, H.; Sharples, S. Eco-Retrofitting very old dwellings: Current and future energy and carbon performance for two UK cities. In Proceedings of the PLEA2013-29th Conference, Sustainable Architecture for a Renewable Future, Munich, Germany, 10-12 September 2013.

27. Berg, F.; Fuglseth, M. Life cycle assessment and historic buildings: Energy-efficiency refurbishment versus new construction in Norway. J. Archit. Conserv. 2018, 24, 152-167. [CrossRef]

28. The Preservation Lab. The Greenest building: Quantifying the environmental Value of building reuse; The Preservation Lab: Washington, DC, USA, 2011.

29. Lönnroth, G. Kulturhistoriskt Värdefull Bebyggelse i Göteborg. Ett Program för Bevarande. Del I och II; Lönnroth, G., Ed.; Göteborgs Stadsmuseum och Göteborgs Stadsbyggnadskontor: Göteborg, Sweden, 1999.

30. Thuvander, L.; Österbring, M.; Mangold, M.; Mata, E.; Wallbaum, H.; Johnsson, F. Spatial exploration of the refurbishment dynamics of urban housing stocks. In Proceedings of the Computers in Urban Planning and Urban Management Conference, CUPUM, MIT, Cambridge, MA, USA, 7-10 July 2015.

31. Tunefalk, M.; Legnér, M. The ROT programme, energy efficiency, and historical values in buildings in sweden 1984-1993. In Proceedings of the the 3rd International Conference on Energy Efficiency in Historic Buildings, Visby, Sweden, 26-27 September 2018; Nilsen, L., Broström, T., Carlsten, S., Eds.; Uppsala University, Department of Art Histor: Visby, Sweden, 2018 ; pp. 255-263.

32. Legnér, M.; Leijonhufvud, G. A Legacy of Energy Saving: The Discussion on Heritage Values in the First Programme on Energy Efficiency in Buildings in Sweden, c. 1974-1984. Hist. Environ. Policy Pract. 2019, 10:1, 40-57. [CrossRef]

33. Antell, O.; Paues, C. Isolering Uppåt Väggarna: En Studie av Tilläggsisolerade hus; Statens råd för Byggnadsforskning: Stockholm, Sweden, 1981; ISBN 9154034094.

34. Femenías, P.; Thuvander, L.; Johansson, P.; Wahlgren, P.; Eriksson, P. Renovating the Housing Stock Built Before 1945: Exploring the Relations Between Energy Efficiency, Embodied Energy and Heritage Values. In CCC 2018: Cold Climate HVAC 2018; Johansson, D., Bagge, H., Wahlström, A., Eds.; Springer: Cham, Switzerland, 2018; pp. 291-301, ISBN 978-3-030-00662-4.

35. Femenías, P.; Jerome, A.; Wahlgren, P.; Johansson, P.; Thuvander, L. Om-Renovering: Möjligheter för Energieffektivisering och Återskapande av Kulturvärden när Flerbostadshus Renoveras på Nytt; Department of Architecture and Civil Engineering (ACE): Gothenburg, Sweden, 2019.

36. Legnér, M.; Leijonhufvud, G.; Tunefalk, M. Energy policy and conservation planning in Sweden: A longitudinal evaluation. Int. J. Build. Pathol. Adapt. 2020, 38, 555-572. [CrossRef]

37. Klõšeiko, P. Deterioration of building envelope of wooden apartment buildings built before 1940 based on external survey. In Proceedings of the 9th Nordic Symposium on Building Physics-NSB, Tampere, Finland, 29 May-2 June 2011; Volume 2, pp. 917-924.

38. Nielsen, A.N.; Jensen, R.L.; Larsen, T.S.; Nissen, S.B. Early stage decision support for sustainable building renovation-A review. Build. Environ. 2016, 103, 165-181. [CrossRef]

39. Mjörnell, K.; Boss, A.; Lindahl, M.; Molnar, S. A tool to evaluate different renovation alternatives with regard to sustainability. Sustainability 2014, 6, 4227-4245. [CrossRef]

40. IVL. Byggsektorns Miljöberäkningsverktyg. Available online: https://www.ivl.se/sidor/vara-omraden/miljodata/ byggsektorns-miljoberakningsverktyg.html (accessed on 15 October 2021).

41. German Federal Ministry of the Interior. Building and Community Ökobaudat Database. Available online: https://www oekobaudat.de/en/home/assessment-system-for-sustainable-building-bnb.html (accessed on 15 October 2021).

42. KBOB. Koordinationskonferenz der Bau—und Liegenschaftorgane der öffentlichen Bauherren Ökobilanzdaten im Baubereich. Available online: https://www.kbob.admin.ch/kbob/de/home/publikationen/nachhaltiges-bauen/oekobilanzdaten_ baubereich.html (accessed on 15 October 2021).

43. Incit AB. Underhållskostnader—REPAB FAKTA; Incit: Mölndal, Sweden, 2017; Available online: https://www.aareon.se/sixcms/ media.php/23/UNDERH\%C3\%85LL\%20Sv\%202018\%20DEMO.pdf (accessed on 15 October 2021). 
44. Tolstoy, N.; Svennerstedt, B. Reparationsbehov i Bostäder och Lokaler, Meddelande; Statens Institut för Byggnadsforskning: Gävle, Sweden, 1984.

45. Lind, H. The Effect of Rent Regulations and Contract Structure on Renovation: A Theoretical Analysis of the Swedish System. Housing Theory Soc. 2015, 32, 389-406. [CrossRef]

46. Brown, N.W.O.; Malmqvist, T.; Bai, W.; Molinari, M. Sustainability assessment of renovation packages for increased energy efficiency for multi-family buildings in Sweden. Build. Environ. 2013, 61, 140-148. [CrossRef]

47. SCB. Snabba Fakta: Flyttar Inom Sverige. Available online: https://www.scb.se/hitta-statistik/sverige-i-siffror/manniskorna-isverige/flyttar-inom-sverige/ (accessed on 15 October 2021).

48. Femenías, P.; Jonsdotter, L.; Knutsson, A.; Mörk, K. Boendes syn på Kulturvärden: Resultat från Enkäter och Intervjuer i Samband Med Renovering av Äldre Flerbostadshus; ACE Rapport 2019:7; Chalmers University of Technology: Gothenburg, Sweden, 2020.

49. Göteborg Energi. Års- och Hållbarhetsredovisning; Göteborg Energi: Gothenburg, Sweden, 2018.

50. Bengt Dahlgren AB Bilaga Till E2B2-Projektet. "Arkitekture, Materialflöden och Relaterad Energianvändning i Bostäder"—Beräkning av Klimatpåverkan för Materialflöde vid Renovering av Bostäder; Bengt Dahlgren: Stockholm, Sweden, 2016.

51. Stedman, R.C.; Connelly, N.A.; Heberlein, T.A.; Decker, D.J.; Allred, S.B. The End of the (Research) World As We Know It? Understanding and Coping With Declining Response Rates to Mail Surveys. Soc. Nat. Resour. 2019, 32, 1139-1154. [CrossRef]

52. Mata, É.; Sasic Kalagasidis, A.; Johnsson, F. Energy usage and technical potential for energy saving measures in the Swedish residential building stock. Energy Policy 2013, 55, 404-414. [CrossRef]

53. Calì, D.; Osterhage, T.; Streblow, R.; Müller, D. Energy performance gap in refurbished German dwellings: Lesson learned from a field test. Energy Build. 2016, 127, 1146-1158. [CrossRef]

54. Haas, R.; Auer, H.; Biermayr, P. The impact of consumer behavior on residential energy demand for space heating. Energy Build. 1998, 27, 195-205. [CrossRef]

55. Dalenbäck, J.-O.; Jagemar, L.; Olsson, D.; Göransson, A.; Nilson, A.; Pettersson, B. Åtgärder för Ökad Energieffektivisering $i$ Bebyggelsen-Underlagsmaterial till Boverkets Regeringsuppdrag Beträffande Energieffektivisering i Byggnader; M2004/4246/Kb; (Measures to Increase the Energy Efficiency in Buildings-Background Report to Boverke); Chalmers EnergiCentrum (CEC): Gothenburg, Sweden, 2005.

56. Public Health Agency of Sweden (Folkhälsomyndigheten). The Public Health Agency of Sweden's Recommendations for Indoor Temperature (Folkhälsomyndighetens Allmänna råd om Temperatur Inomhus); Public Health Agency of Sweden: Solna, Sweden, 2014; pp. 1-10.

57. Boverket Boverkets Byggregler—Föreskrifter och Allmänna Råd; Boverket: Karlskrona, Sweden, 2018; Volume 1, pp. 1-146.

58. Dodoo, A.; Gustavsson, L.; Sathre, R. Life cycle primary energy implication of retrofitting a wood-framed apartment building to passive house standard. Resour. Conserv. Recycl. 2010, 54, 1152-1160. [CrossRef]

59. Erlandsson, M.; Levin, P. Environmental assessment of rebuilding and possible performance improvements effect on a national scale. Build. Environ. 2004, 39, 1453-1465. [CrossRef]

60. Asdrubali, F.; Ballarini, I.; Corrado, V.; Evangelisti, L.; Grazieschi, G.; Guattari, C. Energy and environmental payback times for an NZEB retrofit. Build. Environ. 2019, 147, 461-472. [CrossRef]

61. Beccali, M.; Cellura, M.; Fontana, M.; Longo, S.; Mistretta, M. Energy retrofit of a single-family house: Life cycle net energy saving and environmental benefits. Renew. Sustain. Energy Rev. 2013, 27, 283-293. [CrossRef]

62. Pomponi, F.; Piroozfar, P.A.E.; Southall, R.; Ashton, P.; Pirozfar, P.; Farr, E.R.P. Life cycle energy and carbon assessment of double skin façades for office refurbishments. Energy Build. 2015, 109, 143-156. [CrossRef]

63. Heijungs, R.; Guinée, J.B.; Mendoza Beltrán, A.; Henriksson, P.J.G.; Groen, E. Everything is relative and nothing is certain. Toward a theory and practice of comparative probabilistic LCA. Int. J. Life Cycle Assess. 2019, 24, 1573-1579. [CrossRef]

64. Grant, A.; Ries, R.; Kibert, C. Life cycle assessment and service life prediction: A case study of building envelope materials. J. Ind. Ecol. 2014, 18, 187-200. [CrossRef]

65. European Commission. Shaping More Beautiful, Sustainable and Inclusive Forms of Living Together. Available online: https: / / europa.eu/new-european-bauhaus/index_en (accessed on 15 October 2021). 